LOCKHEED MARTIN

\section{ENVIRONMENTAL RESTORATION PROGRAM}

\section{Project Management Plan for Waste Area Grouping 5 Old Hydrofracture Facility Tanks Content Removal at Oak Ridge National Laboratory, Oak Ridge, Tennessee}




\section{CDM Federal Programs Corporation}

contributed to the preparation of this document and should not be conisdered an eligible contractor for its review.

This report has been reproduced directly from the best available copy.

Available to DOE and DOE contractors from the Office of Scientific and Technical Information, P.O. Box 62, Oak Ridge, TN 37831; prices available from 423-576-8401 (fax 423-576-2865).

Available to the public from the National Technical Information Service, U.S. Department of Commerce, 5285 Port Royal Rd., Springfield, VA 22161. 
Energy Systems Environmental Restoration Program

\title{
Project Management Plan for Waste Area Grouping 5 Old Hydrofracture Facility Tanks Content Removal at Oak Ridge National Laboratory, Oak Ridge, Tennessee
}

Date Issued-July 1996

\author{
Prepared by \\ Engineering Division, \\ Oak Ridge National Laboratory \\ and \\ CDM Federal Programs Corporation \\ Oak Ridge, Tennessee \\ Prepared for the \\ U.S. Department of Energy \\ Office of Environmental Management \\ under budget and reporting code EW 20 \\ Environmental Management Activities at the \\ OAK RIDGE NATIONAL LABORATORY \\ Oak Ridge, Tennessee 37831-6285 \\ managed by \\ LOCKHEED MARTIN ENERGY SYSTEMS, INC. \\ for the \\ U.S. DEPARTMENT OF ENERGY \\ under contract DE-AC05-84OR21400
}




\section{DISCLAIMER}

This report was prepared as an account of work sponsored by an agency of the United States Government. Neither the United States Government nor any agency thereof, nor any of their employees, makes any warranty, express or implied, or assumes any legal liability or responsibility for the accuracy, completeness, or usefulness of any information, apparatus, product, or process disclosed, or represents that its use would not infringe privately owned rights. Reference herein to any specific commercial product, process, or service by trade name, trademark, manufacturer, or otherwise does not necessarily constitute or imply its endorsement, recommendation, or favoring by the United States Government or any agency thereof. The views and opinions of authors expressed herein do not necessarily state or reflect those of the United States Government or any agency thereof. 


\section{DISCLAIMER}

Portions of this document may be illegible in electronic image products. Images are produced from the best available original document. 
Project Management Plan for

Waste Area Grouping 5 Old Hydrofracture Facility

Tanks Content Removal at

Oak Ridge National Laboratory,

Oak Ridge, Tennessee

Approval

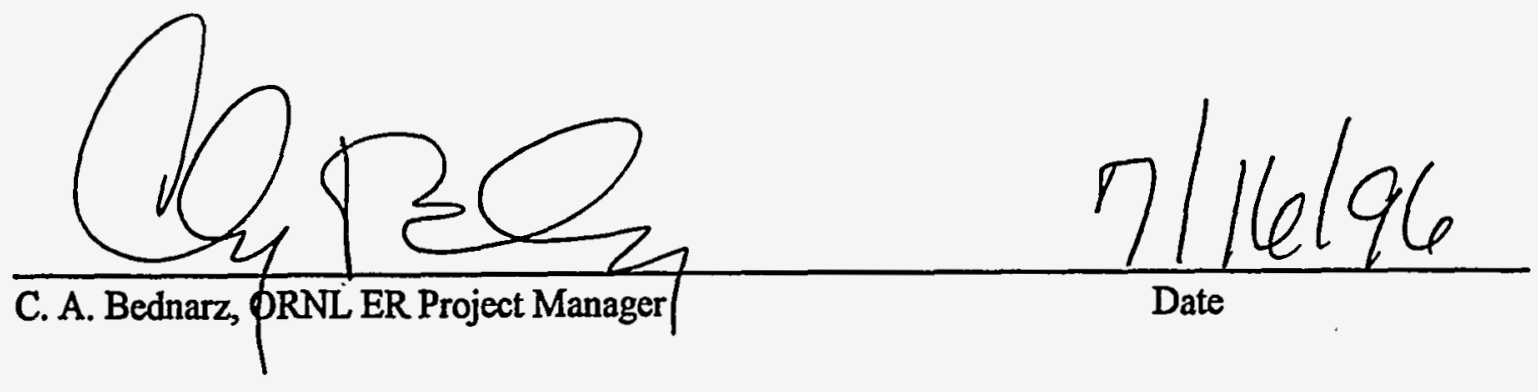




\section{PREFACE}

This project management plan was prepared to describe the organizational responsibilities, schedules, and management controls needed to remove the contents from the five inactive, liquid lowlevel radioactive waste tanks located at the Old Hydrofracture Facility Waste Area Grouping 5 at Oak Ridge National Laboratory. The Program Management Plan for the Martin Marietta Energy Systems, Inc., Oak Ridge National Laboratory Site Environmental Restoration Program, ORNL/ER-167 (Energy Systems 1994) provided the guidance for preparation of this project management plan. This document was prepared under Work Breakdown Structure 6.1.05.20.02 (Activity Data Sheet 3305, "Inactive Tanks"). 


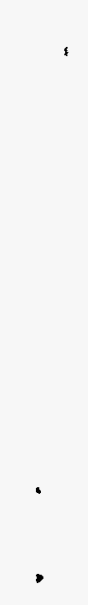




\section{CONTENTS}

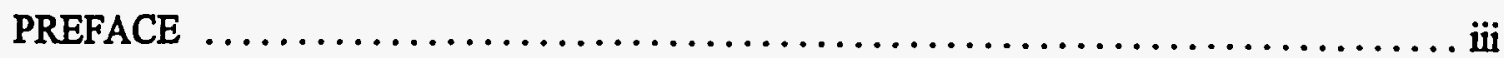

ABBREVIATIONS $\ldots \ldots \ldots \ldots \ldots \ldots \ldots \ldots \ldots \ldots \ldots \ldots \ldots \ldots \ldots \ldots \ldots \ldots \ldots \ldots \ldots$ vii

EXECUTIVE SUMMARY $\ldots \ldots \ldots \ldots \ldots \ldots \ldots \ldots \ldots \ldots \ldots \ldots \ldots \ldots \ldots \ldots \ldots \ldots \ldots \ldots \ldots$

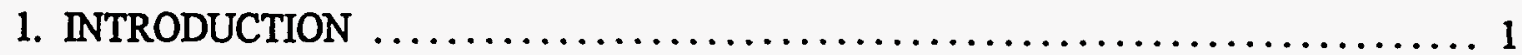

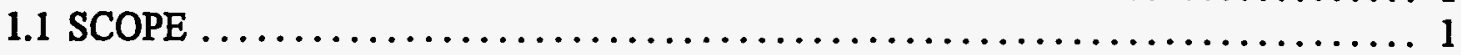

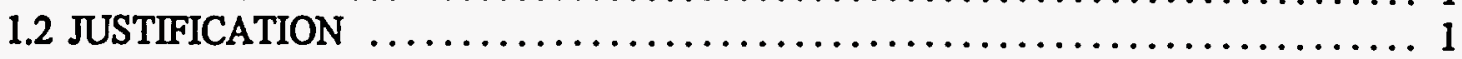

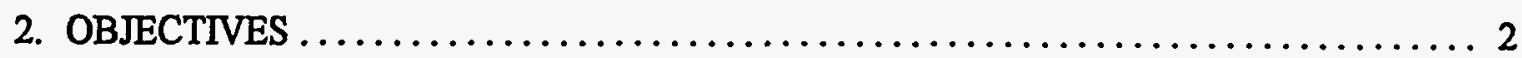

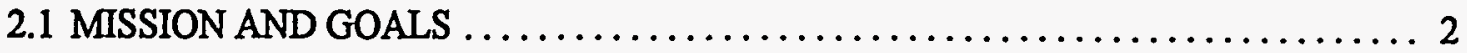

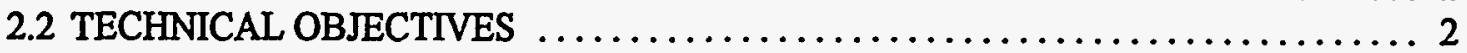

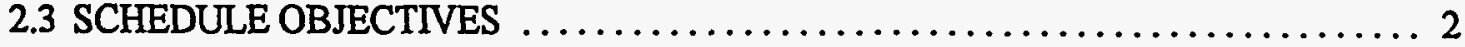

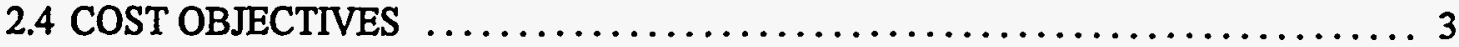

3. MANAGEMENT ORGANIZATION AND RESPONSIBILITIES $\ldots \ldots \ldots \ldots \ldots \ldots \ldots . .$.

3.1 U.S. DEPARTMENT OF ENERGY-OAK RIDGE OPERATIONS OFFICE $\ldots \ldots \ldots \ldots 6$

3.2 LOCKHEED MARTIN ENERGY SYSTEMS, INC. $\ldots \ldots \ldots \ldots \ldots \ldots \ldots \ldots 6$

3.3 ADDITIONAL PARTICIPATING CONTRACTORS AND

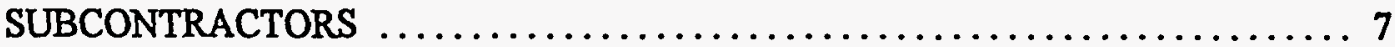

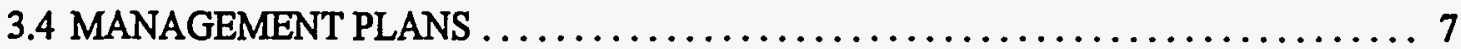

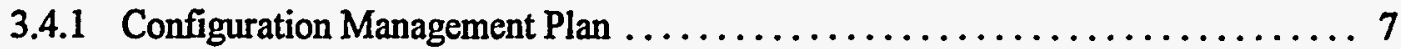

3.4 .2 Waste Management Plan $\ldots \ldots \ldots \ldots \ldots \ldots \ldots \ldots \ldots \ldots \ldots \ldots \ldots$

3.4.3 Project Records Plan $\ldots \ldots \ldots \ldots \ldots \ldots \ldots \ldots \ldots \ldots \ldots \ldots \ldots$

4. WORK PLAN AND PERFORMANCE CRITERIA $\ldots \ldots \ldots \ldots \ldots \ldots \ldots \ldots \ldots$

5. PROJECT SUMMARY WORK BREAKDOWN STRUCTURE $\ldots \ldots \ldots \ldots \ldots \ldots \ldots . .8$

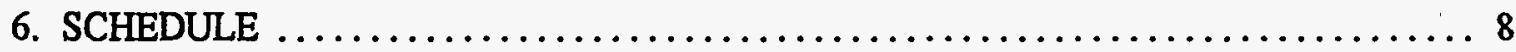

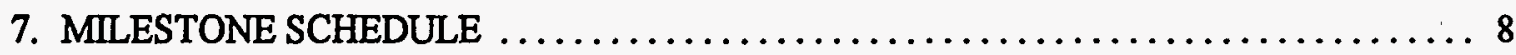

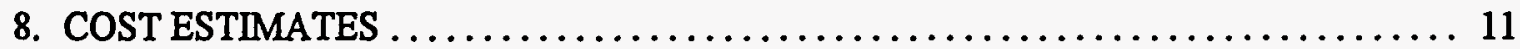

9. COST AND SCHEDULE CHANGE PROCEDURES $\ldots \ldots \ldots \ldots \ldots \ldots \ldots \ldots \ldots \ldots$

10. PROJECT MANAGEMENT, MEASUREMENT, AND PLANNING AND CONTROL SYSTEMS $\ldots \ldots \ldots \ldots \ldots \ldots \ldots \ldots \ldots \ldots \ldots \ldots \ldots \ldots \ldots$

11. INFORMATION AND REPORTING $\ldots \ldots \ldots \ldots \ldots \ldots \ldots \ldots \ldots \ldots \ldots \ldots \ldots \ldots \ldots \ldots \ldots$

12. QUALITY, RISK, SAFETY, AND NEPA DOCUMENTATION $\ldots \ldots \ldots \ldots \ldots \ldots \ldots 12$

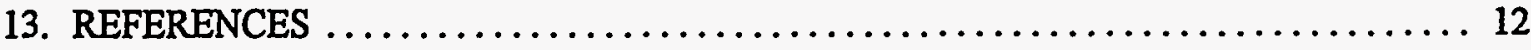




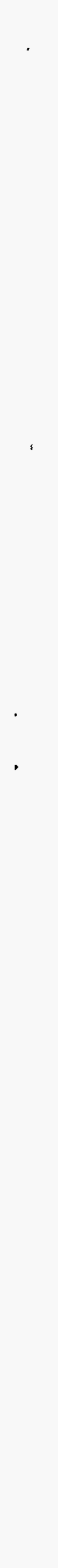




\section{ABBREVIATIONS}

$\begin{array}{ll}\text { BNI } & \text { Bechtel National, Inc. } \\ \text { CARD } & \text { Characterization and Remedial Design } \\ \text { CDM Federal } & \text { CDM Federal Programs Corporation } \\ \text { CERCLA } & \text { Comprehensive Environmental Response, Compensation, and Liability Act of } 1980 \\ \text { DOE } & \text { U.S. Department of Energy } \\ \text { EE/CA } & \text { engineering evaluation and cost analysis } \\ \text { Energy Systems } & \text { Lockheed Martin Energy Systems, Inc. } \\ \text { EPA } & \text { U.S. Environmental Protection Agency } \\ \text { ER } & \text { Environmental Restoration } \\ \text { FFA } & \text { Federal Facility Agreement } \\ \text { Jacobs } & \text { Jacobs ER Team } \\ \text { LLLW } & \text { liquid low-level (radioactive) waste } \\ \text { MK-Ferguson } & \text { MK-Ferguson of Oak Ridge Company } \\ \text { MVST } & \text { Melton Valley Storage Tanks } \\ \text { NEPA } & \text { National Environmental Policy Act } \\ \text { OHF } & \text { Old Hydrofracture Facility } \\ \text { ORNL } & \text { Oak Ridge National Laboratory } \\ \text { ORO } & \text { Oak Ridge Operations Office (DOE) } \\ \text { QA } & \text { quality assurance } \\ \text { TDEC } & \text { Tennessee Department of Environment and Conservation } \\ \text { USQD } & \text { Unreviewed Safety Questions Determination } \\ \text { WAG } & \text { Waste Area Grouping } \\ \text { WBS } & \text { work breakdown structure } \\ \text { WMRAD } & \text { Waste Management and Remedial Action Division } \\ \end{array}$





\section{EXECUTIVE SUMMARY}

This document identifies the roles and responsibilities of the project team members and identifies the project scope, schedule, and cost reporting activities for a Comprehensive Environmental Response, Compensation, and Liability Act non-time critical removal action to remove the contents from the five Old Hydrofracture Facility (OHF) tanks (T-1, T-2, T-3, T-4, and T-9) located in Waste Area Grouping 5 at Oak Ridge National Laboratory (ORNL).

This document has been reviewed against, and is intended to be consistent with, the U.S. Department of Energy-Oak Ridge Operations Office Environmental Restoration (ER) program management plan. The program management plan for the Lockheed Martin Energy Systems, Inc., ORNL ER program provided the guidance for preparing this plan.

The scope of this project is to transfer the liquid and sludge contents from the five inactive liquid low-level (radioactive) waste (LLLW) tanks at the OHF into the active LLLW system and remediate the remaining OHF tank shells. Elements of the project include sampling and analysis, preparing a characterization report, evaluating the tanks, developing an engineering assessment and cost analysis, preparing an action memorandum, designing and constructing a support facility (pipeline and tie-in to valve box) to permit access to the active LLLW system, removing the contents of the tanks, and transferring the contents of the tanks to the active LLLW system.

The OHF LLLW tanks contain approximately 42,000 gal of low-level radioactive waste consisting of both supernatant and sludge. The primary off-site human health risks, which provide the justification for this removal action, are the presence of approximately $30,000 \mathrm{Ci}$ of radioactive material in the tanks, the fact that the single-wall tanks are constructed of carbon steel and buried without active corrosion protection (the tanks were buried in the early 1960 s and the cathodic protection system was found to be inoperative in the early 1990s), and the existence of an expedient pathway to public receptors via the under-tank drain system that discharges into Melton Branch and White Oak Creek.

A substantial future off-site risk is posed to human health and the environment by the contents of these five tanks. Removing and disposing of the contents from the inactive OHF LLLW tanks will reduce the consequence of a potential release from the tanks and, therefore, reduce this future off-site risk potential. 


\section{INTRODUCTION}

The purpose of the Old Hydrofracture Facility (OHF) tanks content removal project is to transfer inventory from the five OHF tanks (T-1, T-2, T-3, T-4, and T-9) located in Waste Area Grouping (WAG) 5 at Oak Ridge National Laboratory (ORNL) to the Melton Valley Storage Tanks (MVST) liquid low-level (radioactive) waste (LLLW) storage facility, and remediate the remaining OHF tank shells. The major activities involved are identified in this document along with the organizations that will perform the required actions and their roles and responsibilities for managing the project.

\subsection{SCOPE}

On January 1, 1992, the U.S. Department of Energy (DOE), the U.S. Environmental Protection Agency (EPA) Region IV, and the Tennessee Department of Environment and Conservation (TDEC) signed a Federal Facility Agreement (FFA) concerning the Oak Ridge Reservation. The FFA requires that inactive LLLW tanks at ORNL be remediated in accordance with requirements of the Comprehensive Environmental Response, Compensation, and Liability Act (CERCLA).

The scope of this project is to transfer inventory from the five inactive LLLW tanks at the OHF into the active LLLW system and remediate the remaining OHF tank shells. Elements of the project include sampling and analysis, including tank evaluation; preparing a characterization report; developing an engineering evaluation and cost analysis $(\mathrm{EE} / \mathrm{CA})$; preparing an action memorandum; designing and constructing a support facility (pipeline and tie-in to valve box) to gain access to the active LLLW system; removing the contents of the tanks; and, subsequently, remediating the remaining tank shells.

The inventory transfer will be accomplished using existing commercial sluicing and pumping technologies. All work activities will be performed in an economic manner compliant with all applicable DOE orders, procedures of Lockheed Martin Energy Systems, Inc. (Energy Systems), and environmental, safety, and health regulations.

\subsection{JUSTIFICATION}

The OHF LLLW tanks contain approximately 42,000 gal of low-level radioactive waste consisting of both supernatant and sludge. The primary human health risks, which provide the justification for the removal actions, are the presence of approximately $30,000 \mathrm{Ci}$ of radioactive material in the tanks, the fact that the single-wall tanks are constructed of carbon steel and buried without active corrosion protection (the tanks were buried in the early 1960s and the cathodic protection system was found to be inoperative in the early 1990s), and the existence of an expedient pathway to public receptors via the under-tank drain system that discharges into Melton Branch and White Oak Creek.

A substantial future off-site risk is posed to human health and the environment by the contents of these five tanks. Removing and disposing of the contents from the inactive OHF LLLW tanks will reduce the consequences of a potential release from the tanks and, therefore, reduce this future off-site risk potential. 


\section{OBJECTIVES}

\subsection{MISSION AND GOALS}

The mission of the DOE Environmental Restoration (ER) Program is to either eliminate or reduce to prescribed safe levels the risks to the environment and to human health and safety posed by inactive or surplus DOE-managed sites and facilities that have been contaminated by radioactive, hazardous, or mixed wastes. This mission is to be accomplished in conformance with all federal, state, and local environmental statutes and regulations.

The goal of the WAG 5 OHF Inactive Tanks project team is to sluice, to the extent practicable, the current inventory (both liquid and sludge) in the inactive OHF tanks and transfer the inventory to the active LLLW system. Transfer will be accomplished by using existing sluicing technologies and equipment coupled with constructing a new pipeline/valve box tie-in as needed to complete the transfer. After the transfer has been completed, the remaining tank shells will be remediated. Work activities will be performed in compliance with all applicable DOE Orders; Energy Systems procedures; and environmental, safety, and health regulations.

\subsection{TECHNICAL OBJECTIVES}

The technical objectives of the OHF tanks content removal project are to remove the contents from the OHF tanks, transfer the contents to the active LLLW system, and remediate the remaining tank shells. The project will consist primarily of the following major work packages:

- establish clear and concise data quality objectives for all sampling and analyses information needed to satisfy the active LLLW system waste acceptance criteria and engineering design considerations;

- sample and analyze the contents of the OHF tanks;

- prepare an $\mathrm{EE} / \mathrm{CA}$ and action memorandum;

- perform preliminary engineering, prepare installation drawings and specifications, construct piping and ancillary equipment and systems to transfer the OHF tanks content to the active LLLW system; and

- conduct the CERCLA removal action.

\subsection{SCHEDULE OBJECTIVES}

The proposed schedule objectives for the OHF tanks content removal project are to submit the final removal action memorandum for DOE approval in the fall of 1996, start removal action field activities in the summer/fall of 1997, and complete tank remediation activities and site restoration activities by the fall of 1998. To ensure adherence to the overall project schedule, more detailed activities and milestones have been established. The project summary schedule is shown in Sect. 6 and important project control milestones are listed in Sect. 7. 


\subsection{COST OBJECTIVES}

The proposed cost objective for this project is to accomplish tanks content removal at minimum cost while meeting all regulatory requirements. Cost and schedule performance will be evaluated against the performance baseline established in the FY 1996 Task Work Agreement and the FY 1997 Incentive Task Order.

Once a technical solution has been defined in the action memorandum, a preliminary cost estimate as defined in the U.S. Department of Energy-Oak Ridge Operations Office (DOE-ORO) ER Program management plan (DOE-ORO 1990) will be developed. A detailed cost estimate for the removal action will be prepared when a definitive design is completed.

\section{MANAGEMENT ORGANIZATION AND RESPONSIBILITIES}

The ORNL ER Program organization and the roles and responsibilities of the key management positions are described in Sect. 3 of the Energy Systems program management plan (Energy Systems 1994).

The responsibilities and duties of the major participants in this specific project are described in Sects. 3.1 through 3.3 of this document and in Sect. 4 of the Energy Systems program management plan (Energy Systems 1994). The organizational structure for implementation of the OHF tanks content removal project is shown in Fig. 1.

The project will be managed by the Energy Systems ER organization on behalf of DOE-ORO. Support activities will be provided to Energy Systems from Energy Systems Engineering Division personnel, and from Energy Systems subcontractors, including the MK-Ferguson of Oak Ridge Company (MK-Ferguson). The Energy Systems Waste Management and Remedial Action Division (WMRAD) will oversee the actual sluicing and pumping activities [performed by Bechtel National, Inc. (BNI)], and the Jacobs ER Team (Jacobs) will prepare the decision documents for the project. The following sections identify specific individuals, describe more fully the responsibilities of these individuals and the various organizations involved, and provide information on reporting requirements. Figure 2 summarizes project responsibilities. 


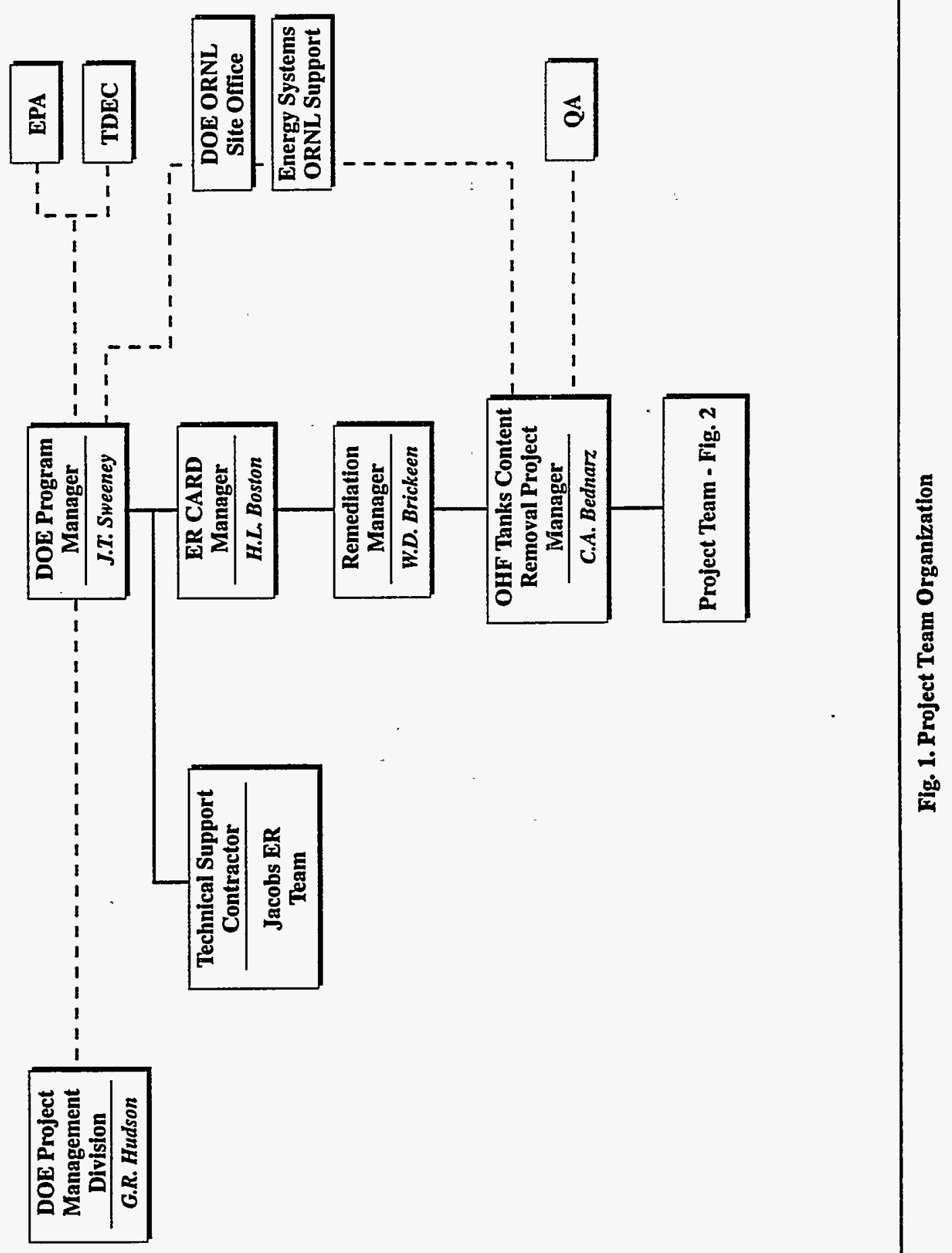




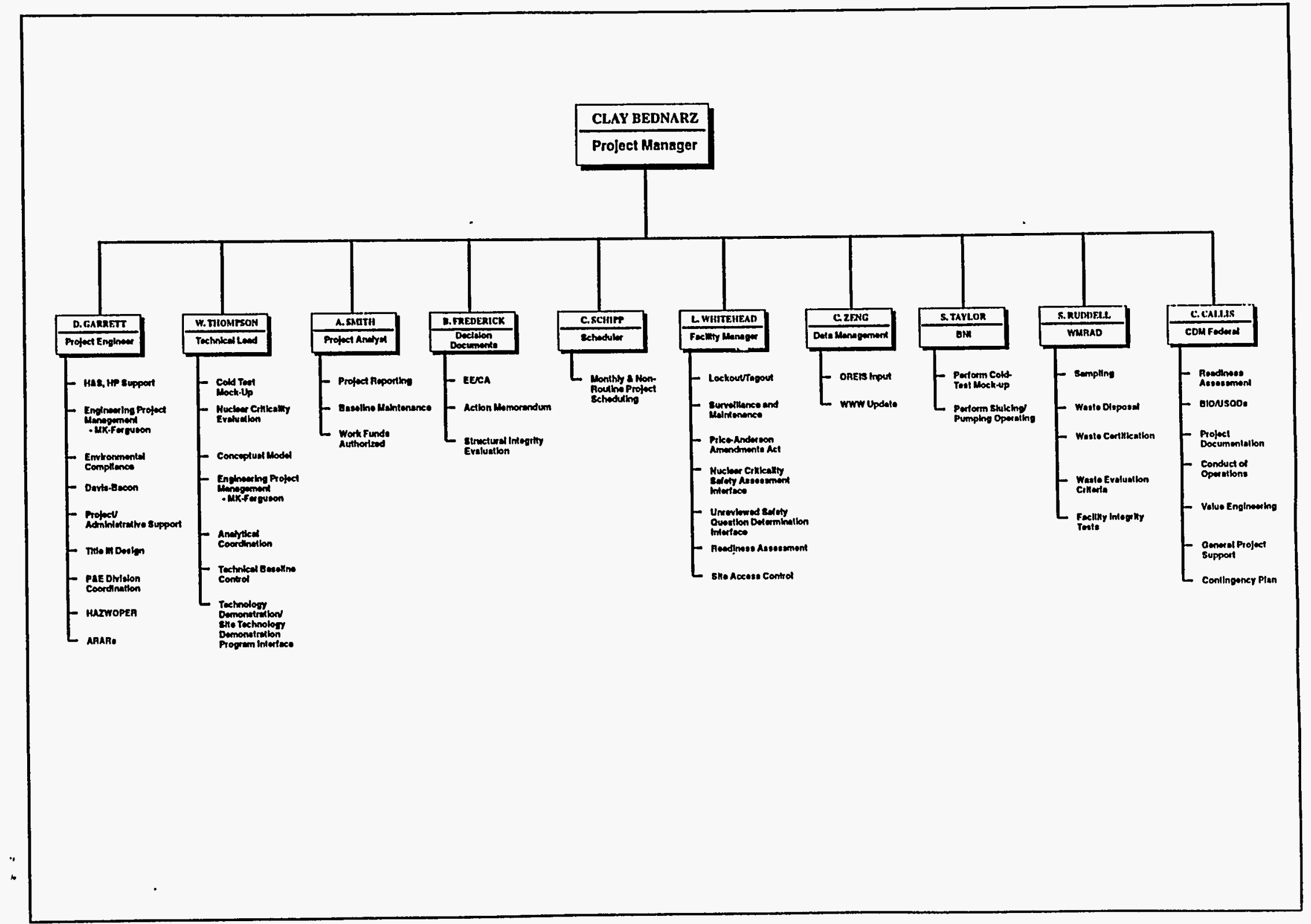




\subsection{U.S. DEPARTMENT OF ENERGY-OAK RIDGE OPERATIONS OFFICE}

DOE-ORO is ultimately responsible for all activities on the Oak Ridge Reservation. DOE-ORO will provide overall project management and administration of all prime contracts. All participants will be under contract to DOE-ORO or its contractors. Any coordination with EPA and TDEC will be DOE's responsibility.

\subsection{LOCKHEED MARTIN ENERGY SYSTEMS, INC.}

Energy Systems is the management and operating prime contractor at ORNL under an existing costplus-award-fee prime contract. Energy Systems will have overall responsibility for project management and integration; Titles I, II, and III activities; provision of environmental, safety, and health support services and plans for the fieldwork (e.g., waste management plan); and provision of project and subcontractor management services.

The Energy Systems project manager is Clay Bednarz, who will have overall responsibility for ensuring that the project's scope is accomplished within the specified budget and schedule. Bednarz will have primary responsibility for interfacing with $\mathrm{DOE}$ and the regulatory community. Within the Energy Systems organization, the following individuals will report to Bednarz on OHF Removal Action Project issues and will be responsible for accomplishing the described activities.

- Don Garrett, Energy Systems, is the project engineer and will be responsible for coordinating all engineering tasks in support of the project. Garrett will coordinate health physics and health and safety support for all field activities, all regulatory compliance issues, Davis-Bacon documentation, Titles I and II design work, Plant and Engineering Division activities, hazardous waste operations and emergency response requirements, and development of applicable and relevant or appropriate requirements for the remedial action. Garrett will also coordinate the activities performed by MKFerguson, and will provide general project administrative support. Garrett will enlist subcontractor support for these activities, including Chris Provost, CDM Federal Programs Corporation (CDM Federal).

- Warren Thompson, Energy Systems, is the technical lead for the project and will coordinate the cold-test mock-up activities, the nuclear criticality evaluations, development of the site conceptual model, sampling and analytical laboratory work. He will also maintain technical baseline control and provide interface for the Technical Demonstration and Site Technology Demonstration Program. Thompson will coordinate all work performed by MK-Ferguson.

- Amy Smith, Energy Systems, is the project analyst and will maintain the budget and reporting requirements for the project.

- Brian Frederick, Jacobs, will be responsible for preparing all decision documents for the project, including the EE/CA and the Action Memorandum.

- Chuck Schipp, Energy Systems, is the project scheduler and will maintain and update the schedule for the project and all scheduled activities within the project.

- Lynn Whitehead, Energy Systems, is the facility manager for the OHF and has site landlord responsibilities for all activities conducted on-site. These responsibilities include lockout/tagout control, surveillance and maintenance activities, Price-Anderson Amendments Act duties, interface 
for Nuclear Criticality Safety Assessments, Unreviewed Safety Questions Determination (USQD) interface, readiness assessment interface, and site access control.

- Cindy Zeng, Energy Systems, is the project data management specialist and is responsible for maintaining all project data, Oak Ridge Environmental Information System interface, maintenance of the OHF home page on the ORNL server, and general World Wide Web updates.

- Stewart Taylor, BNI, will be responsible for conducting the cold-test mock-up and the sluicing operations. Procedures will be developed from the cold-test mock-up for use during the actual sluicing. This will ensure that the readiness assessment requirements for a category 3 nuclear facility are met.

- Steve Ruddell, WMRAD, will coordinate all WMRAD activities on behalf of the project. These activities will include conduct of all sampling of the tanks, oversight of the sluicing and pumping tasks, waste certification and disposal of all remedial action-derived waste, waste evaluation criteria review, and all facility integrity tests.

- Charles Callis, CDM Federal, will be responsible for coordinating all readiness assessment activities for the project, coordinating USQD and Basis for Interim Operation preparation, preparation of project documentation, value engineering, and general project support.

\subsection{ADDITIONAL PARTICIPATING CONTRACTORS AND SUBCONTRACTORS}

MK-Ferguson will prepare the site support facilities. The following activities will be included: (1) installation of additional tank risers for enhanced tank access, (2) installation of a new pipeline and tie-in to an existing valve box for transfer of OHF tanks inventory to MVST via the existing LLLW pipeline, (3) general preparation of the site, and (4) field assembly of the sluicing system components. Participation by MK-Ferguson assumes that the development of the support facilities will be deemed a construction activity by the Davis-Bacon Committee. MK-Ferguson personnel will perform these activities under the direction of. Garrett and. Thompson.

\subsection{MANAGEMENT PLANS}

The following sections describe various management plans that will be prepared for the project.

\subsubsection{Configuration Management Plan}

No safety class items or safety systems are involved in this project. Upon completion of the removal action, the system configuration will be documented on as-built drawings in accordance with Energy Systems Engineering Procedure EP-C-35.

Configuration management activities will be consistent with Annex $\mathrm{C}$ of the Management Plan for the Oak Ridge Operations Environmental Restoration Program (DOE-ORO 1991). A separate projectspecific configuration management plan will not be prepared. 


\subsubsection{Waste Management Plan}

Energy Systems will prepare a waste management plan to address the management of wastes produced during the implementation of the tanks content removal action. The waste management plan will be consistent with the Waste Management/Waste Certification Plan for the Oak Ridge National Laboratory Environmental Restoration Program, ORNL/ER-288 (Energy Systems 1995).

\subsubsection{Project Records Plan}

A project records plan in accordance with Engineering Procedure EP-B-36 will be prepared by Energy Systems and will be followed by each participant.

\section{WORK PLAN AND PERFORMANCE CRITERIA}

The ER Program and WMRAD will oversee the removal of contents from the tanks in accordance with the system components and requirements, environmental safety and health documents, waste management plan, and related requirements that will be developed for this project.

\section{PROJECT SUMMARY WORK BREAKDOWN STRUCTURE}

The project summary work breakdown structure (WBS) is shown in Fig. 3. All project participants will manage and schedule work, collect costs, and report at the project summary WBS level 6 or lower.

\section{SCHEDULE}

The draft project schedule is displayed in Fig. 4.

\section{MILESTONE SCHEDULE}

Project control milestones are listed in Table 1. 


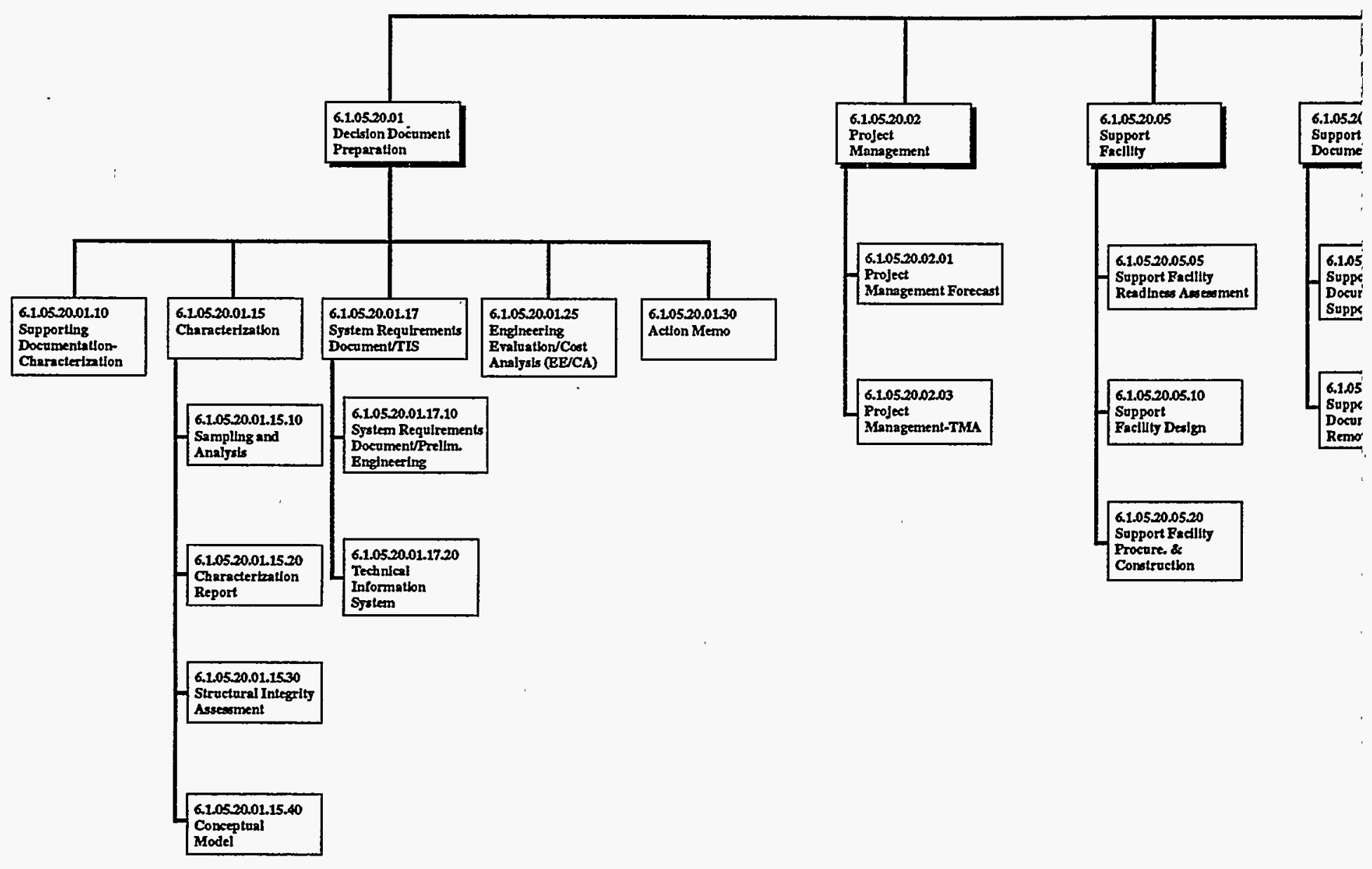




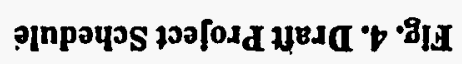

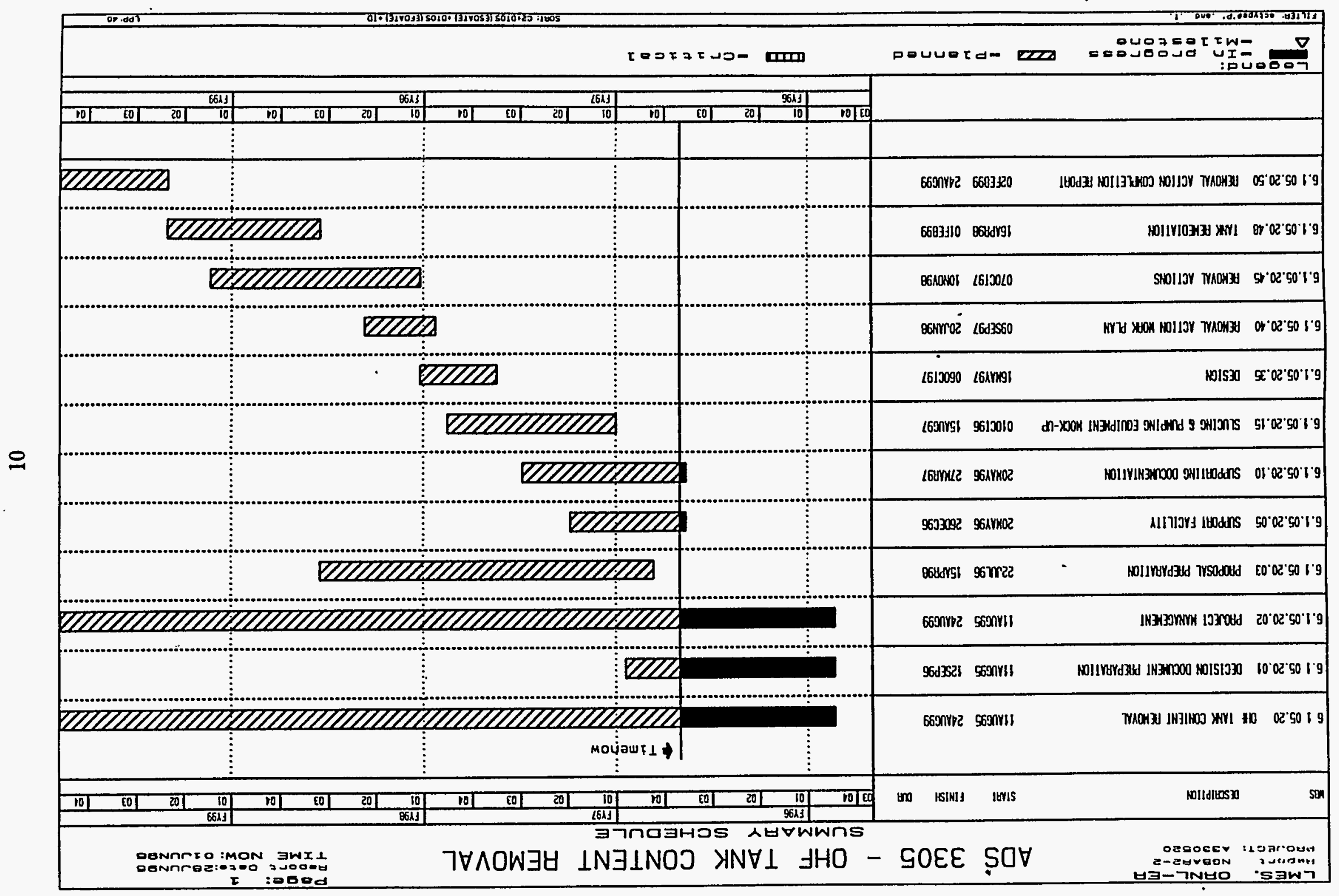


Table 1. Old Hydrofracture Facility tanks content removal project control milestones

\begin{tabular}{lc}
\hline \multicolumn{1}{c}{ Description } & Date \\
\hline Issue approved Sampling and Analysis Plan Addendum & $12 / 13 / 95$ \\
Submit Characterization Report to DOE for approval & $4 / 2 / 96$ \\
Submit EE/CA to DOE for approval & $6 / 6 / 96$ \\
Submit removal action memorandum to DOE for approval & $\mathrm{TBD}$ \\
Issue approved removal action work plan & $\mathrm{TBD}$ \\
Complete removal action & $\mathrm{TBD}$ \\
Submit post-remediation report to EPA and TDEC for regulatory review & $\mathrm{TBD}$ \\
\hline
\end{tabular}

\section{COST ESTIMATES}

A cost estimate of approximately $\$ 7.5 \mathrm{M}-\$ 10.0 \mathrm{M}$ was derived by using Automated Estimating System Standard Value File ERAUG95A.VAL, August 1995. Estimates are made on the basis of assumptions by the project team members who are familiar with the size, history, and character of the facilities and the most probable cleanup activities.

\section{COST AND SCHEDULE CHANGE PROCEDURES}

The baseline cost estimate will be regularly reviewed and updated, as required, to ensure that the estimate reflects the latest authorized scope, schedule, and method of accomplishment in accordance with DOE-ORO change control policy.

Cost and schedule change procedures will be consistent with DOE Management Control Systems and ER Program requirements. All changes in the estimated cost and schedule will be documented to provide continuity between estimates and schedules.

\section{PROJECT MANAGEMENT, MEASUREMENT, AND PLANNING AND CONTROL SYSTEMS}

Integrated DOE and Energy Systems cost accounting and Management Control Information Systems will be used to manage, evaluate, and provide reports concerning the cost, schedule, and technical performance of this project. 


\section{INFORMATION AND REPORTING}

Typical data to be received by the Energy Systems project manager from other contractors and integrated into the actual cost and schedule performance data include the following:

1. cost performance reports;

2. status reports containing funding information to track budget authorizations and budget outlays, commitments, and accrued costs; and

3. reports concerning progress, accomplishments, problems, impacts, and corrective actions.

- The Energy Systems project manager and project analyst will prepare the project monthly status report and issue the report for consolidation with ER Program reports.

\section{QUALITY, RISK, SAFETY, AND NEPA IDOCUMENTATION}

A quality assurance (QA) evaluation; a QA project plan, if required by the QA evaluation; a risk assessment/plan; a nuclear criticality safety assessment; and a safety assessment will be prepared, as required, for this project.

The QA plan for the DOE-ORO ER Program has been published as Part I of the Environmental Restoration and Waste Management Program Quality Assurance Plan (DOE-ORO 1990). Project participants will be required to comply with the overall plan. Participants may implement compliance either by adopting the Energy Systems QA plan and procedures directly or by following their own approved equivalent procedures. Lower-tier documents will be prepared by project participants as required to meet project-specific $Q A$ requirements. Copies of all $Q A$ requirements will be transmitted to Energy Systems, which will ensure the proper filing of all documents for DOE.

Energy Systems Environmental Compliance Division will either document that categorical exclusion CX-XIO-442 (3042X), Removal from Service and/or Permanent Closure of Liquid LowLevel Radioactive Waste Tank System at ORNL, provides the required National Environmental Policy Act (NEPA) documentation for this project or will provide any additional required NEPA documentation.

\section{REFERENCES}

DOE-ORO (U.S. Department of Energy - Oak Ridge Operations Office) 1990. Environmental Restoration and Waste Management Program/Quality Assurance Plan, Part I, DOE/ORO-916, Oak Ridge, Tennessee. Prepared by PAI Corporation.

DOE-ORO (U.S. Department of Energy - Oak Ridge Operations Office) 1990. Management Plan for the Oak Ridge Operations Environmental Restoration Program, DOE/ORO-931, Oak Ridge, Tennessee. 
Energy Systems (Martin Marietta Energy Systems, Inc.) 1994. Program Management Plan for the Martin Marietta Energy Systems, Inc., Oak Ridge National Laboratory Site Environmental Restoration Program, ORNL/ER-167, Oak Ridge National Laboratory.

Energy Systems (Martin Marietta Energy Systems, Inc.) 1995. Waste Management/Waste Certification Plan for the Oak Ridge National Laboratory Environmental Restoration Program. ORNL/ER288. 


\section{DISTRIBUTION}

1. L. V. Asplund

2. C. A. Bednarz

3. H. L. Boston

4. W. D. Brickeen

5. D. L. Garrett

6. L. Hawk

7-8. P. T. Owen

9. D. M. Matteo

10. S. Ruddell

11. P. A. Schrandt

12. A. Smith

13. D. C. White

14. M. L. Whitehead

15. C. Zeng

16. Central Research Library

17. ER Document Management Center-RC

18. C. L. Callis, CDM Federal Programs

19. C. Provost, CDM Federal Programs

20. B. Frederick, Solutions For Environmental Problems, Inc.

21. S. Taylor, Bechtel National, Inc.

22. B. Womble, M-K Ferguson, Inc.

23. Office of Scientific and Technical Information, P. O. Box 62, Oak Ridge, TN 37831 